\title{
透析液流量および透析時間の違いによる溶質除去能の検討
}

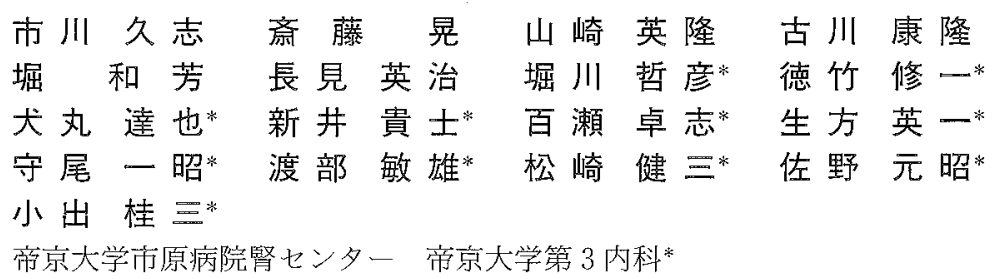

key words：透析液流量，透析時間，除去率，除去量，KT/V

〈要旨〉

維持血液透析患者に，透析液流量 $(\mathrm{QD})$ ，透析時間，血流量 $(\mathrm{QB})$ を変更し，关の際小分子量物質として尿素窒 素 (UN)，クレアチニン $(\mathrm{Cr})$ ，尿酸 $(\mathrm{UA})$ ，無機リン (iP)，中分子量物質としてピーク $2 \mathrm{a}$ ，低分子量蛋白として $\beta_{2}-M G$ の除去率，除去量の比較検討を行った。また，QBを変更した時のUrea の KT $/ \mathrm{V}$ ，TACBUN を測定し比較検 討した。

結果は, (1) QDを $500 \mathrm{ml} / \mathrm{min}$ と $400 \mathrm{ml} / \mathrm{min}$, (2) 透析時間を 4 時間と 5 時間で透析したときの各小分子量物質, ピーク 2aおよび $\beta_{2}-\mathrm{MG}$ の除去率では有意差は認められなかったが, 除去量では UN, Cr, UA, iP, ピーク 2a， $\beta_{2}-$ MG それ光れに有意な差が認められた。(3) KT/V，TACBUNは目標値とされている範囲内での変動であり，除去率と 同様 KT/V 值のみを指標とすることは慎重でなければならないと思われた。今回の成績から，透析条件として QD は $400 \mathrm{ml} / \mathrm{min} よ り は 500 \mathrm{ml} / \mathrm{min}$ が，透析時間は 4 時間よりは 5 時間が望ましいと考えられた。

\section{The effect on the rate and amount of removal of various substances by changes in dialysis flow, dialysis time and blood flow}

Hisashi Ichikawa, Akira Saito, Hidetaka Yamazaki, Yasutaka Hurukawa, Kazuyoshi Hori, Eiji Nagami, Tetsuhiko Horikawa*, Shyuichi Tokutake*, Tatsuya Inumaru*, Takashi Arai*, Takashi Momose*, Eiichi Ubukata*, Kazuaki Morio*, Toshio Watabe*, Kenzo Matsuzaki*, Motoaki Sano*, Keizo Koide*

Teikyo University Ichihara Hospital Hemodialysis Center ; Third Department of Internal Medicine, Teikyo University

The effect on the rate and amount of removal of low molecular weight substances (UN, Cr, UA, iP), middle molecular weight substances (peak-2a) and low molecular proteins $\left(\beta_{2}-M G\right)$ following changes in dialysis flow, dialysis time and blood flow were examined in hemodialysis patients. In addition the effect on the KT/V of urea and TACBUN by changes in blood flow was examined. The removal rate of all substances studied did not differ between a $500 \mathrm{ml} / \mathrm{min}$ rate of dialysate flow and a $400 \mathrm{ml} / \mathrm{min}$ rate of dialysate-flow, nor between four or five hour hemodialysis. The total removal amounts of all substances tested for, at a dialysate flow of $500 \mathrm{ml} / \mathrm{min}$ over a five hour hemodialysis period were higher than at a dialysate flow of $400 \mathrm{ml} / \mathrm{min}$ over a four hour period of hemodialysis.

The KT/V of urea and TACBUN at a blood-flow rate of $280 \mathrm{ml} / \mathrm{min}$ were higher than at a blood flow rate of

市川 久志 篣京大学市原病院腎センター 厈299-01 市原市姉㥓 3426-3 (0436-62-1211)

〔受付：平成 7 年 10 月 27 日, 受理: 平成 8 年 2 月 15 日〕 
$220 \mathrm{ml} / \mathrm{min}$, but remained within normal limits.

From these results, we concluded that a rate of dialysis flow of $500 \mathrm{ml} / \mathrm{min}$ was more effective than $400 \mathrm{mll}$ min for the removal amount of various substances, and that five-hour-hemodialysis was more effective than hemodialysis over a four hour period for the removal amount.

\section{緒言}

血液透析に扔いて透析量を決定する条件として $\mathrm{QB}, \mathrm{QD}$, 透析器, 透析時間, 限外濾過量 (除水量) などがあるが，最近は透析器の性能(溶質除去能， 除水能）が向上したことや経済的な面から透析液 の減量が検討されており，高血流量にしてハイパ フォーマンス透析器を使用することより透析液の 減量が可能ではないか。との報告がある ${ }^{1,2)}$ 。

今回我々は, 安定維持透析患者において QD, 透 析時間を変更しその際の各溶質の除去率，除去量 を測定しさらにQB を変更したときの除去率，除 去量抢よび Ureaの $\mathrm{KT} / \mathrm{V}$ ，TACBUN を測定し 比較検討したので報告する。

\section{対象}

対象は当院において血液透析を行っている安定 維持透析患者 24 名。内訳注男 10 名, 女 14 名で平 均年齢は 56.4 土13.4 歳, 原疾患は, 慢性系球体腎 炎 18 名, 糖尿病性腎症 6 名, 透析歴は平均 46.6 办 月である。

\section{方法}

1。同一患者で透析条件のうち QD，透析時間お よび QB を下記のように変更し, UN, Cr, UA, iP, ピーク $2 \mathrm{a}, \beta_{2}-\mathrm{MG}$ の除去率, 除去量の比較検討 を行った。

1) QD $500 \mathrm{ml} / \mathrm{min}$ と $400 \mathrm{~m} l / \mathrm{min}$.

2 ) 透析時間 4 時間と 5 時間。

3) $\mathrm{QB}$ 平均 $220 \mathrm{ml} / \mathrm{min}$ と平均 $280 \mathrm{ml} / \mathrm{min}$.

2。同一患者でUrea の KT/V, TACBUN につ いて下記の比較検討を行った。

1) QD $500 \mathrm{ml} / \mathrm{min}$ と $400 \mathrm{ml} / \mathrm{min}$.

2) $\mathrm{QB}$ 平均 $220 \mathrm{ml} / \mathrm{min}$ と平均 $280 \mathrm{ml} / \mathrm{min}$. な招使用透析器は PS-1.6 UW 15 名, FB-150 U 6 名, AM-BC-150 P 3 名である。除去量は透析 液排液を 1 時間毎に全量貯留し擋挥しその一部を 2 本採取し， 2 検体の平均濃度に排液量をかけ， 1 時間每の溶質量を算出し, 最後に毎時間の溶質

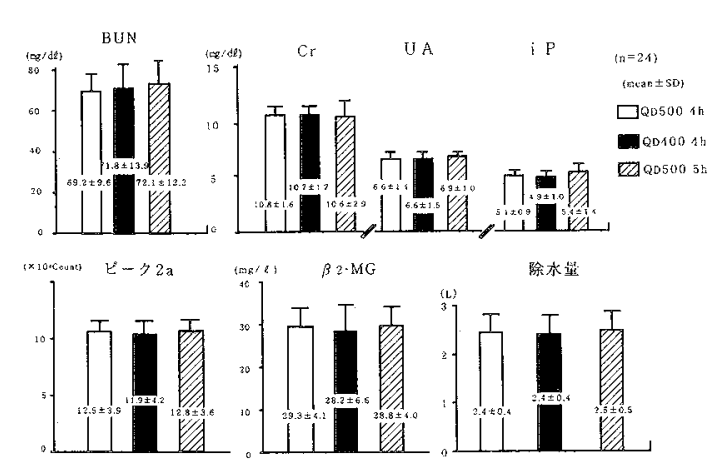

図 1 各溶質の透析前值䇽よび除水量

量を合計した。ピーク 2 a は HPLC 装置を用い井 上らふの方法により測定した。

\section{結果}

1。各溶質の透析前値および除水量

対象者 24 名の QD $500 \mathrm{ml} / \mathrm{min} 4$ 時間, QD 400 $\mathrm{m} l / \mathrm{min} 4$ 時間, QD $500 \mathrm{~m} l / \mathrm{min} 5$ 時間それぞれ で透析した時の UN, Cr, UA, iP, ピーク $2 \mathrm{a}, \beta_{2}$ $\mathrm{MG}$ 各溶質の透析前值，除水量に有意差は認めら れなかった（図 1)。

\section{2。小分子量物質の除去率}

QD $500 \mathrm{ml} / \mathrm{min} 4$ 時間, $400 \mathrm{ml} / \mathrm{min} 4$ 時間, $500 \mathrm{ml} / \mathrm{min} 5$ 時間透析施行時の UN, Cr, UA, iP の除去率ではそれぞれの間に有意差は認められな かった（図 2)。

\section{3 . 小分子量物質の除去量}

QD $500 \mathrm{~m} l / \mathrm{min} 4$ 時間, $400 \mathrm{ml} / \mathrm{min} 4$ 時間, $500 \mathrm{ml} / \mathrm{min} 5$ 時間透析施行時の UN, Cr, UA, iP の除去量では全てにおいて有意差を認め $500 \mathrm{ml}$ min 5 時間透析で最も多く除去され，次いで 500 $\mathrm{ml} / \mathrm{min} 4$ 時間透析 $400 \mathrm{ml} / \mathrm{min} 4$ 時間透析の順 であった(図 3 )。

4。ピーク 2 a おび $\beta_{2}-\mathrm{MG}$ の除去量

ピーク $2 \mathrm{a}, \beta_{2}-\mathrm{MG}$ ともに QD $500 \mathrm{ml} / \mathrm{min} 5$ 時間透析で最も高い除去量を示し，次いで500 $\mathrm{m} l / \mathrm{min} 4$ 時間, $400 \mathrm{ml} / \mathrm{min} 4$ 時間の順であった 

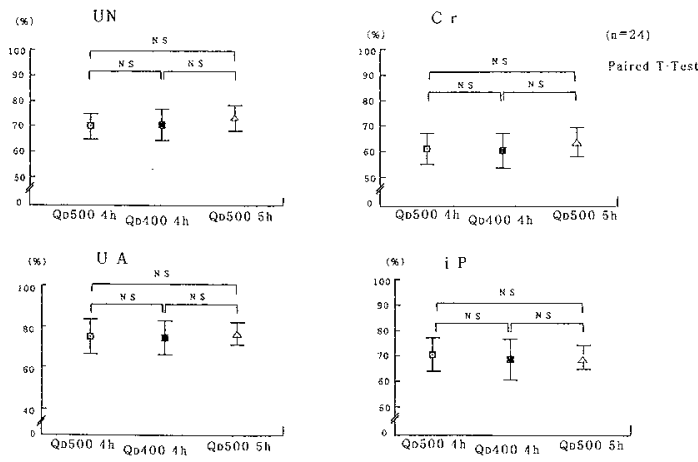

図 2 小分子量物質の除去率
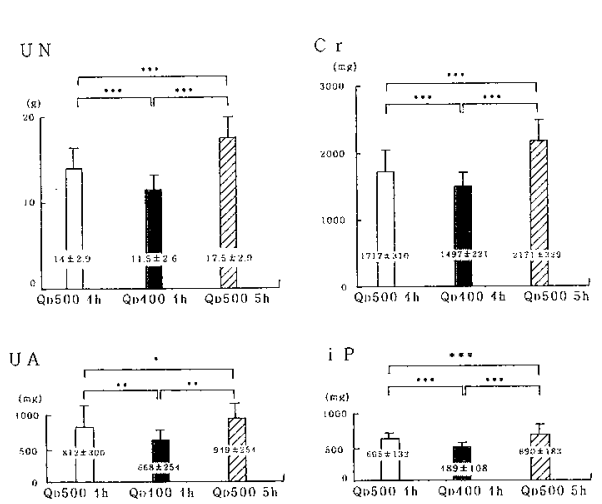

図 3 小分子量物質の除去量

(図 4 )。

5.QD 変更時の $\mathrm{UN}, \mathrm{Cr}, \mathrm{iP}, \beta_{2}-\mathrm{MG}$ の除去量 の経時変化

QD $500 \mathrm{~m} / / \mathrm{min}, 4$ 時間と QD $400 \mathrm{~m} / / \mathrm{min}$, 4 時間の 1 時間毎の比較ではそれぞれの溶質除去 量が QD $500 \mathrm{ml} / \mathrm{min} ， 4$ 時間において全体的に高 值を示す傾向にあった（図５）。

6 。透析時間変更時の $\mathrm{UN}, \mathrm{Cr}, \mathrm{iP}, \beta_{2}-\mathrm{MG}$ の 除去量の経時変化

図 6 にD $500 \mathrm{ml} / \mathrm{min}$ と一定にして，4 時 間透析と 5 時間透析の際の $\mathrm{UN}, \mathrm{Cr}, \mathrm{iP}, \beta_{2}-\mathrm{MG}$ の除去量の経時变化の比較を示す。 $\mathrm{QB}$ ，透析器は 変更しなかったので 5 時間透析では 5 時間目の除 去量が加算されることになる。5時間透析では UN で約 $2 \mathrm{~g}, \mathrm{Cr}$ で $250 \mathrm{mg}$, iP で $100 \mathrm{mg}, \beta_{2}-\mathrm{MG}$ では $200 \mathrm{mg}$ 程度の除去量の増加が認められた。

7。QB変更時の小分子量物質㜿よびピーク $2 \mathrm{a}$,
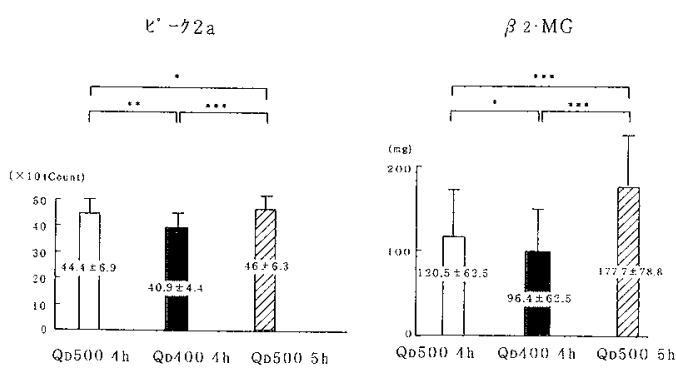

$\{n=24\}$ Paired T-Test

- $p(0,0) 5$

.. $\mathrm{p} \times 0.01$

... $P \notin 0.001$

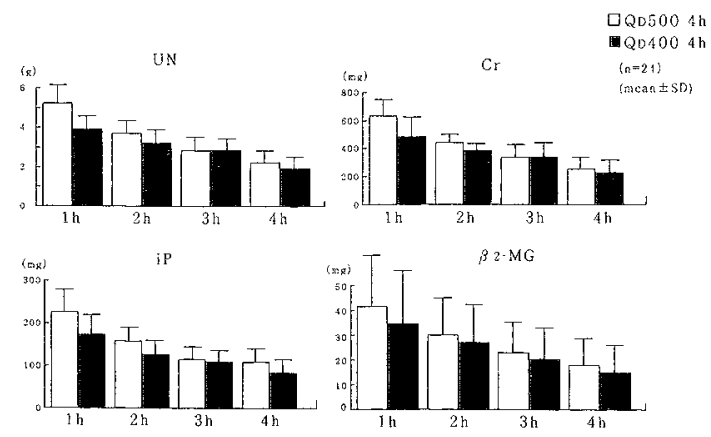

図 5 QD 変更時の UN, Cr, iP, $\beta_{2}-\mathrm{MG}$ の除去量 の経時変化
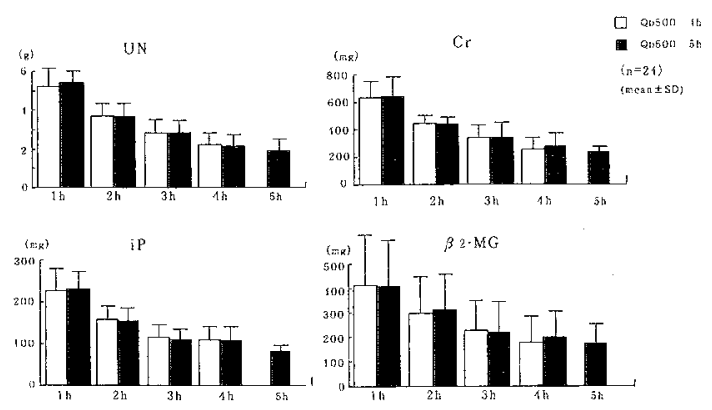

図 6 透析時間変更時の $\mathrm{UN}, \mathrm{Cr}, \mathrm{iP}, \beta_{2}-\mathrm{MG}$ の 除去量の経時変化

$\beta_{2}-\mathrm{MG}$ の除去量

QD $500 \mathrm{ml} / \mathrm{min}$ として, QB 平均 $280 \mathrm{ml} /$ $\min$ と平均 $220 \mathrm{ml} / \mathrm{min}$ にした時の UN, Cr, UA, $\mathrm{i}$, ピーク 2 a および $\beta_{2}-\mathrm{MG}$ の除去量を示す。 $280 \mathrm{ml} / \mathrm{min}$ のと $\mathrm{UN}, \mathrm{Cr}, \mathrm{iP}$ の除去量に有意な 増加が認められたが UA は増加傾向はみられた 

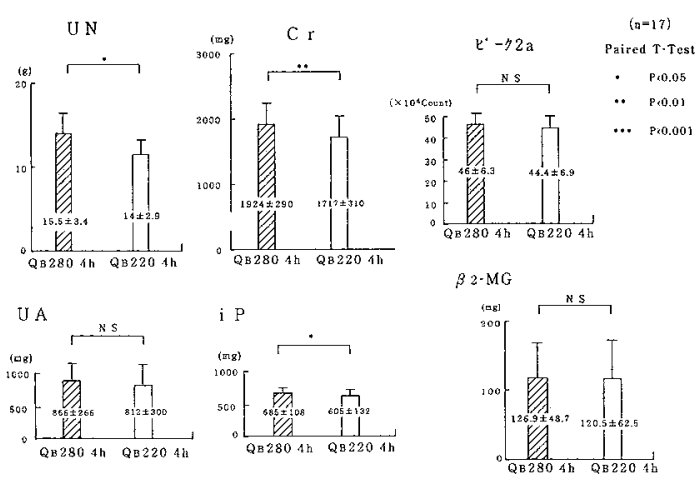

図 7 QB 変更時の小分子量物質およびピーク $2 \mathrm{a}$, $\beta_{2}-\mathrm{MG}$ の除去量

ものの有意差はなかった。またピーク $2 \mathrm{a}, \beta_{2}-\mathrm{MG}$ では僅かに増加傾向を認めたが有意差は認められ なかった（図7)。

8、QD，QB を変更したときの $\mathrm{KT} / \mathrm{V} と \mathrm{TAC}$ BUN の比較

(1) QD $500 \mathrm{ml} / \mathrm{min}, \mathrm{QB}$ 平均 $220 \mathrm{ml} / \mathrm{min}$ (2) QD $400 \mathrm{ml} / \mathrm{min}, \mathrm{QB}$ 平均 $220 \mathrm{ml} / \mathrm{min}$ 抢よび (3) QD $500 \mathrm{ml} / \mathrm{min}$, QB 平均 $280 \mathrm{ml} / \mathrm{min}$ 透析時の $\mathrm{KT} /$ $\mathrm{V}$ と TACBun の比較を示す。 KT/V は QD 500 $\mathrm{m} l / \mathrm{min}$, QB $280 \mathrm{ml} / \mathrm{min}$ の時最も高值を示し, 次いで QD $500 \mathrm{ml} / \mathrm{min}$, QB $220 \mathrm{ml} / \mathrm{min}$, QD 400 $\mathrm{m} l / \mathrm{min}$ ，QB $220 \mathrm{ml} / \mathrm{min}$ の順でありそれぞれに 有意差が認められた。

TACBUN では QD $500 \mathrm{ml} / \mathrm{min}$, QB $280 \mathrm{ml}$ $\min$ の時最も低值を示し, QD $500 \mathrm{ml} / \mathrm{min}, \mathrm{QB}$ $220 \mathrm{ml} / \mathrm{min}$, QD $400 \mathrm{ml} / \mathrm{min}$, QB $220 \mathrm{ml} / \mathrm{min}$ の 順でありそれぞれに有意差を認めた（図 8 )。

\section{考察}

1. QD そついて

通常，血液透析の QD は一般には $500 \mathrm{ml} / \mathrm{min}$ が用いられているが，最近透析器の溶質除去能が 向上したことや経済的な面から透析液の減量が検 討されており, 高血流量にして高性能透析器を使 用することより $300 \mathrm{ml} / \mathrm{min} \sim 400 \mathrm{ml} / \mathrm{min}$ 程度 に減少できるのではないか，との報告がある ${ }^{1,2)}$ 我久は 4 時間透析での QD $500 \mathrm{ml} / \mathrm{min}$ と 400 $\mathrm{m} l / \mathrm{min}$ の除去率を比較検討した結果 UN, Cr, $\mathrm{UA}, \mathrm{iP}$, ピーク $2 \mathrm{a}, \beta_{2}-\mathrm{MG}$ に有意差は認められ

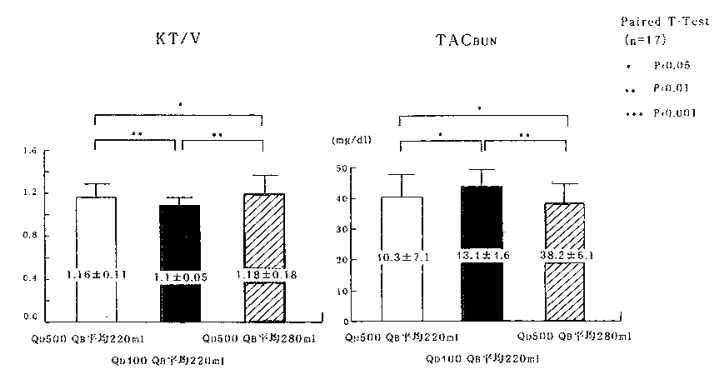

図 8 QD を変更したときとQB を変更したとき の $\mathrm{KT} / \mathrm{V}, \mathrm{TACBUN} の$ 比較

なかった。除去率は，体重，QB，QD，透析時間， などの条件により左右される年といわれている が，今回はクロスオーバーでの比較なのでそれら についての影響は少ないと思われる。また細胞内 から細胞外へさらに血中へ速やかに移行するもの は血中濃度の変化が少ないので除去率の変化も少 ないが，除去量は増加するので除去率に差はみら れないが除去量には差がみられたと考えられる。

特に除去率で気をつけなければならないのは iP である。iP は透析後半での血中の level-off や rebound 現象が報告されているおり年占，我々も透 析 5 時間值での血中濃度の上昇傾向を経験してお り除去率で論ずるのは困難であると思われる。排 液除去量では QD $400 \mathrm{~m} / / \mathrm{min} 4$ 時間において UN で約 $2.5 \mathrm{~g}, \mathrm{Cr}$ で $200 \mathrm{mg}$, UA で $100 \mathrm{mg}$, iP で $100 \mathrm{mg}, \beta_{2}-\mathrm{MG}$ で $20 \mathrm{mg}$ 程度の減少がみ られた。除去量は透析器により $\beta_{2}-\mathrm{MG}$ の吸着等 も考慮しなければならないが，同じ透析条件での 比較検討では除去率で差が認められず，除去量で 差が認められたことより除去率のみを指標にする のは慎重にしなければならないと思われた。

2.QDについて

QD $500 \mathrm{ml} / \mathrm{min}$ 一定とし, QB 平均 $220 \mathrm{ml}$ $\min$ と $280 \mathrm{~m} l / \mathrm{min}$ にした時の各溶質の除去率, 除去量をみた。QB 増加させた場合，小分子量物 質のクリアランスは増加するが中分子量物質およ び低分子量蛋白のクリアランスはそれほど増加せ ず，中分子量物質，低分子量蛋白のクリアランス に影響するのは透析器の膜面積と濾過速度といわ れている ${ }^{7 \sim 9)}$ 。今回の除去量の検討でも小分子量物 質では $\mathrm{QB}$ を増加させた時の $\mathrm{UN}, \mathrm{Cr}, \mathrm{iP}$ では有 
意差を認めたが，透析時間 4 時間，除水量約 $2.5 l$ の条件下では UN で約 $1.5 \mathrm{~g}, \mathrm{Cr} て ゙ 200 \mathrm{mg}$, iP で $80 \mathrm{mg}$ 程度の増加でありそれほど効果的な除 去ではないと思われた。

UA では上昇傾向にはあったが有意差は認めら れず，ピーク $2 \mathrm{a} ， \beta_{2}-\mathrm{MG}$ では有意差は認められ なかつた。QBについては，適切な $\mathrm{QB}$ 決定や $\mathrm{QB}$ を増加させたときの心循環系への影響についての

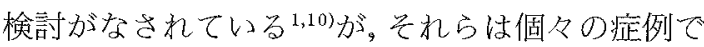
異なり心疾患などの合併症やシャント流量不足， 透析中の血圧低下などがなければ高血流量も可能 と思われるが，成人では $150 \mathrm{~m} l / \mathrm{min} \sim 250 \mathrm{ml}$ min として諸因子を考慮して個々のQB 学決定し ている報告があり ${ }^{1)}$ 太田 ${ }^{8}$ は QB をむやみに增や すことは心臓への負担増にもつながるため，成人 患者に対して通常 $200 \mathrm{~m} l / \mathrm{min}$ 程度のQB で透析 を施行することは比較的効率がよく合理的である と述べている。今回，QB $280 \mathrm{~m} l / \mathrm{min}$ に増加した 対象者 24 名中 7 名が血圧低下により drop out し たことを考慮すると，溶質の除去効率を目的とし てQB だをむやみに上げることは慎重でなけれ ばならないと考えられる。

3 。透析時間について

透析時間は溶質（尿素， $\mathrm{Cr}$ ，尿酸， $\beta_{2}-\mathrm{MG}$ 等） の除去量を決定する最も重要な条件の一つであ り，透析時間を短縮するのであればこれに伴う溶 質の除去量の減少をその他の透析条件の変更によ り補わなければならない。しかし溶質の分子量が 異なればダイアライザークリアランスの及ぼす諸 透析条件のインパクトも異なるのでそれらを考慮

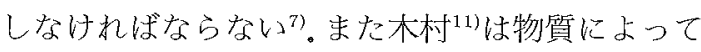
は細胞内自身で産生され，また細胞内の濃度が高 く細胞外で低く，細胞外濃度を低下させても細胞 外への物質移動は活とんど促進しない物質 (iP がそれに近い動態を示す）もあり，短時間透析で は除去量不足になる可能性が大きいと考光られ る。また中分子量物質以上の物質の除去が短時間 透析で低下することは避けられない事実であり， 小分子量物質のコントロール基準のみを頼りに短 時間透析を進めていくことは誤りといわざるを得 ないと述べている。今回，透析時間 4 時間と 5 時
間と比較したが，5時間透析において UN で約 $2.2 \mathrm{~g}$ ，Cr で $290 \mathrm{mg}$ ，iP で $100 \mathrm{mg} ， \beta_{2}-\mathrm{MG}$ で $200 \mathrm{mg}$ 程度の増加があり除去量の有意な差が認 められたことより透析時間を 4 時間以下に短縮す ることは慎重でなければならないと考无られる。

4. KT/Vについて

$\mathrm{KT} / \mathrm{V}$ ，TACBUNについてはQD を減少したと きと $\mathrm{QB}$ を増加したときで比較検討したが $\mathrm{KT} /$ $\mathrm{V}$ ，TACBUNともに有意差は認められたものの $\mathrm{KT} / \mathrm{V}$ では 1.1〜1.2, TACBUN では 45〜35 mg/ $\mathrm{d} l$ であり適正といわれている範囲内 ${ }^{22)}$ での変動で あった。KT/V を指標にする場合，1）尿素の体 内分布スペースを 1 つ大きな混合槽とすること への疑問 2 ) 透析中の除水が考慮されていない 3 ) 限外濾過（除水）によっても若干量除去されるが それが考慮されていない 4 ）透析中の尿素の産生 量が考慮されていない 5 ) 透析中のさまざまな変 動要因が考慮されていないなどの問題点がある ${ }^{13)}$ との指摘があるが,我々は透析排液を全量貯留し， $\mathrm{K}=$ 総排液量 $/($ Cpre + Cpost $) \mathrm{t}$ を用い，考慮して いるのでそれらの因子の影響は比較的少ないと思 われる。

\section{まとめ}

1) QD $500 \mathrm{ml} / \mathrm{min}$ から $400 \mathrm{ml} / \mathrm{min}$,ま た透析時間を 4 時間， 5 時間に変更した時の各小 分子量物質，中分子量物質ピーク 2 a 㜿よび $\beta_{2}$ $\mathrm{MG}$ の除去率には有意な差がみられなかったが 除去量には有意差が認められた。

2) $\mathrm{KT} / \mathrm{V}$ は目標とされる範围内 $(1.0 \sim 1.2)$, また TACBUNも範囲内 $(65 \mathrm{mg} / \mathrm{d} l)$ での変動で あった。

以上の成績より透析条件のうち，透析液流量は $400 \mathrm{ml} / \mathrm{min}$ よりは $500 \mathrm{ml} / \mathrm{min}$ が，また透析時 間は 4 時間よりは 5 時間が望ましいと考えられ た。

本論文の要旨は第 40 回日本透析医学会において 発表した

\section{文献}

1) Cambi V, Savszzi G, Aris L : Short dialysis 
Schedules (SDS)-finally ready to become a routine? Proc Eur Dial Trans Assoc 11: 112 $-120,1974$

2) 斉藤 博：透析技術の再検討。臨牀透析 12 ： 1891-1897，1987

3）井上 昇，小出桂三，上床 周，遠山純子，山 崎善弥, 和田達雄, 琾 隆弘, 織田敏次, 上原 康夫，中尾正明：高速クロマトグラフィーによ る腎不全血漿の分析法の開発と臨床応用。人工 臓器 $9: 41-44,1980$

4) 平沢由平：透析療法マニュアル。透析器の効率, p 115-117, 1989

5) Sugisaki H, Onohara M, Kunitomo $T$ : Phosphate in dialysis patients. Trans Am Soc Antif Intern Organs 29:38-43, 1983

6）斧原三恵子，国友哲之輔，杉崎弘章：慢性透析 患者 $(\mathrm{P})$ の動態一 $\mathrm{P}$ kinetics の検討一。人工 臟器 $12: 670-675,1983$

7）新里高弘，小沢袸子，前田憲志：中分子量物質
と低分子蛋白の除去からみた短時間透析。臨牀 透析 $18: 311-316,1992$

8）太田和夫：人工腎臟の実際(改訂第 4 版)。ダイ アライザーの機能評価。p 38-50, 南汇堂, 東京, 1993

9）吉山直樹，丸茂文昭：血液净化療法（上巻）膜 物質輸送理諭，透析一血液透析一。p 11-17, 1991

10）新里高弘，小沢祐子，前田憲志：中分子量物質 と低分子蛋白の除去からみた短時間透析。臨牀 透析 $18: 311-316,1992$

11）木村玄次郎：小分子量物質の除去からみた短時 間透析。臨將透析 3 : 299-304, 1992

12) Gotch FA, Sargent JA : A mechanic analysis of National Cooperative Dialysis Study (NCDS). Kidney Int 28:536-540, 1985

13) 峰島三千男: 透析効率. KT/V. 医器学 65 : 41-44, 1995 